\title{
STUDI OBSERVASI ASESMEN PERKEMBANGAN BAHASA ANAK (STUDI KASUS DI TK JOGJA GREEN SCHOOL)
}

\author{
Riris Wahyuningsih \\ Institut Agama Islam Ibrahimy Banyuwangi \\ Email: riris.pgra15@gmail.com
}

\begin{abstract}
The purpose of this research is to find out how the implementation of language development assessment in early childhood in kindergarten Jogja Green School Yogyakarta. This study uses naturalistic qualitative methods. The results of the study show that there are several indicators used in the assessment of children's language development in kindergarten Jogja Green School Yogyakarta, namely connecting simple writing with the symbol that symbolizes it, performing 2-3 simple commands, can mention self-identity, writing letters that are introduced, telling stories on a bench stage, retelling a story in the right fabric, listening to poetry and being able to repeat, and telling the contents of the series drawings.
\end{abstract}

Keywords: Assessment, Language Development, Early Childhood

\begin{abstract}
Abstrak
Tujuan dari penelitian ini adalah untuk mengetahui bagaimana pelaksanaan asesmen perkembangan bahasa pada anak usia dini di TK Jogja Green School Yogyakarta. Penelitian ini menggunakan metode kualitatif naturalistic. Adapun hasil penelitian menunjukkan bahwa terdapat beberap indikator yang digunakan dalam asesmen perkembangan bahasa anak di TK Jogja Green School Yogyakarta, yaitu menghubungkan tulisan sederhana dengan simbol yang melambangkannya, melakukan 2-3 perintah sederhana, dapat menyebutkan identitas diri, menulis huruf-huruf yang dikenalkan, bercerita dengan panggung bangku, menceritakan kembali sebuah cerita dengan jalinan yang benar, mendengarkan syair dan mampu mengulang kembali, dan menceritakan isi gambar seri.
\end{abstract}

Kata kunci: Asesmen, Perkembangan Bahasa, Anak Usia Dini 


\section{PENDAHULUAN}

Perkembangan merupakan suatu perubahan yang berlangsung seumur hidup dengan bertambahnya struktur dan fungsi tubuh yang lebih kompleks dalam kemampuan gerak kasar, gerak halus, bicara dan bahasa serta sosialisasi dan kemandirian. Ciri-ciri pertumbuhan dan perkembangan anak antara lain, menimbulkan perubahan, berkolerasi dengan pertumbuhan, memiliki tahap yang berurutan dan mempunyai pola yang tetap. Perkembangan berbicara dan menulis merupakan suatu proses yang menggunakan bahasa ekspresif dalam membentuk arti. Perkembangan berbicara pada awal dari anak yaitu menggumam maupun membeo. Menurut pendapat Dyson bahwa perkembangan berbicara terkadang individu dapat menyesuaikan dengan keinginannya sendiri, hal ini tidak sama dengan menulis. Seorang bayi dari hari ke hari akan mengalami perkembangan bahasa dan kemampuan bicara, namun tentunya tiap anak tidak sama persis pencapaiannya, ada yang cepat berbicara ada pula yang membutuhkan waktu agak lama. Untuk membantu perkembangannya ibu dapat membantu memberikan stimulasi yang disesuaikan dengan keunikan masing-masing anak.

Sejalan dengan perkembangan kemampuan serta kematangan jasmani terutama yang bertalian dengan proses bicara, komunikasi tersebut makin meningkat dan meluas, misalnya dengan orang di sekitarnya lingkungan dan berkembang dengan orang lain yang baru dikenal dan bersahabat dengannya. Terdapat perbedaan yang signifikan antara pengertian bahasa dan berbicara. Bahasa mencakup segala bentuk komunikasi, baik yang diutarakan dalam bentuk lisan. tulisan, bahasa isyarat, bahasa gerak tubuh, ekspresi wajah pantomim atau seni. Sedangkan bicara adalah bahasa lisan yang merupakan bentuk yang paling efektif untuk berkomunikasi, dan paling penting serta paling banyak dipergunakan. Perkembangan bahasa tersebut selalu meningkat sesuai dengan meningkatnya usia anak. Orangtua sebaiknya selalu memperhatikan perkembangan tersebut, sebab pada masa ini, sangat menentukan proses belajar. Hal ini dapat. dilakukan dengan memberi contoh yang baik, memberikan motivasi pada anak untuk belajar dan sebagainya.

Mengacu pada persoalan tersebut dan dalam rangka menghadapi era globalisasi, program pendidikan harus mampu memberikan bekal kepada peserta didik untuk memiliki daya saing yang tinggi dan tangguh, sehingga dapat menyesuaikan perubahan-perubahan yang terjadi di berbagai bidang kehidupan di masyarakat, terutama kemampuan membaca. Sebelum melaksanakan penelitian, penggunaan metode maupun model pembelajarannya kurang menarik, sehingga proses pembelajaran yang terjadi mengalami ketidakberhasilan dengan hasil belajar yang dicapai oleh siswa kurang maksimal, anak cenderung bermain sendiri dan tidak memperhatikan. Karena itu penulis ingin menemukan jalan keluarnya dengan cara melaksanakan penelitian agar dapat diidentifikasikan permasalahan yang melatarbelakangi tidak berhasilnya proses kegiatan belajar tersebut.

Anak yang dianggap banyak berbicara, kadang merupakan cerminan anak yang cerdas. Bahasa mencakup komunikasi non-verbal dan komunikasi verbal serta dapat dipelajari secara teratur tergantung pada kematangan serta kesempatan belajar yang dimiliki seseorang, demikian juga bahasa merupakan landasan seorang anak untuk mempelajari halhal lain. Sebelum anak belajar pengetahuan-pengetahuan lain, anak perlu menggunakan bahasa agar dapat memahami dengan baik. Anak akan dapat mengembangkan kemampuannya dalam bidang pengucapan bunyi, menulis, membaca yang sangat mendukung kemampuan keaksaraan di tingkat yang lebih tinggi.

Setelah kemampuan dalam bahasa didapat, perlunya tindak lanjut untuk melakukan asesmen perkembangan bahasa anak itu sendiri. Tujuan dari pada asesmen adalah tidak lain agar meminimalisir adanya gangguan-gangguan yang mempengaruhi aspek perkembangan bahasa. Pentingnya pelaksanaan asesmen secara tepat sangat penting untuk memberikan 
informasi yang akurat tentang sejauhmana kemajuan perkembangan bahasa yang telah dicapai anak.

\section{METODE PENELITIAN}

Metode penelitian_menggambarkan rancangan penelitian yang meliputi prosedur atau langkah-langkah yang harus ditempuh, waktu penelitian, sumber data, serta dengan cara apa data tersebut diperoleh dan diolah/dianalisis. Dalam prakteknya terdapat sejumlah metode yang biasa digunakan untuk kepentingan penelitian. Adapun jenis penelitian atau pendekatan penelitian yang peneliti lakukan adalah tergolong penelitian kualitatif naturalistic yang lebih mengutamakan data kualitatif. Sedangkan metode yang digunakan adalah evaluasi kualitatif dengan jenis penelitian dengan bentuk studi komperatif. Dimana menurut suharsimi arikunto, istilah "naturalistic" menunjukkan bahwa pelaksanaan penelitian ini memang terjadi alamiah, apa adanya, dalam situasi normal yang tidak dimanipulasi keadaan, menekankan pada deskripsi secara alami. Dengan sifatnya ini akan dituntut keterlibatan peneliti secara langsung dilapangan (Arikunto, 2012).

\section{HASIL DAN PEMBAHASAN}

\section{Kondisi TK Jogja Green School}

TK Jogja Green School yang terletak di dusun Jambon RT4/RW 22 Trihanggo Gamping - Sleman - DIY memiliki konsep pembelajaran yang berbeda dari TK yang lainnya dimana suasana sendiri lingkungan sekolah yang emnggunakan konsep alam, dengan tujuan tidak adanya batas bermain anak serta menumbuhkan rasa cinta lingkungan dan memberikan pandangan kepada siswa untuk kembali kealam sebagaimana kita dahulu.

Pada saat penelitian, terlihat bahwa pembelajaran di Jogja Green School, dilaksanakan dengan berbagai kegiatan yang menarik yang dilaksanakan dengan bermain. Anak-anak terlihat aktif dalam mengikuti kegiatan yang dilaksanakan pada saat itu. Kegiatan pembelajaran di Jogja Green School terlihat berjalan dengan teratur, artinya sudah ada pembagian waktu yang jelas antara kegiatan bermain dan penjelasan terkait dengan tema pada hari tersebut. Pada saat penelitian, kegiatan pembelajaran di Jogja Green School, terlihat matang, artinya proses kegiatan pembelajaran yang berlangsung di Jogja Green School berlangsung dengan lancar sesuai dengan rencana kegiatan yang sebelumnya telah disusun oleh guru. Pada saat penelitian, guru atau pendidik di Jogja Green School terlihat kreatif dalam melaksanakan kegiatan pembelajaran. Guru memiliki peran yang sangat penting dalam proses pembelajaran. Seorang guru memiliki peran dan kewajiban untuk membangun dan membantu tumbuh kembang anak dalam pembelajaran agar anak dapat mengembangkan kreativitasnya secara optimal. Hal demikian sependapat dengan Yeni Rachmawati dan Euis Kurniati menyatakan guru adalah tokoh bermakna dalam kehidupan anak (Rachmawati \& Kurniati, 2005).

Pada saat penelitian di Jogja Green School, terlihat adanya komunikasi dan hubungan yang baik antara guru (pihak sekolah) dengan orang tua. Hubungan yang terjalin tersebut mempunyai dampak yang positif bagi perkembangan kreativitas anak, dimana antara orangtua dan guru dapat berkomunikasi dan berbagi informasi terkait dengan pertkembangan anak khususnya perkembangan kreativitas anak. Selain itu, juga terdapat buku penghubung kepada orang tua, sehingga orang tua dapat melihat perkembangan anak dan dapat menyampaikan informasi melalui buku penghubung tersebut. Pada saat penelitian, orang tua di Jogja Green School, mempunyai hubungan yang intensif dengan guru maupun dengan pihak sekolah, sehingga dapat membantu untuk mengambangkan kreativitas anak. Hal demikian sependapat dengan Yeni Rachmawati dan Euis Kurniati, yang menyatakan bahwa kreativitas anak akan 
berkembang dengan baik jika orang tua dan lingkungan keluarga mendukung (Rachmawati \& Kurniati, 2005).

Orang tua atau keluarga mempunyai peranan yang sangat besar untuk membantu mengembangkan potensi yang dimiliki oleh anak. Berdasarkan hasil penelitian, hasil wawancara kepada guru maupun coordinator lembaga dan observasi di ketahui bahwa proses pembelajaran di laksanakan secara menyenangkan dan semenarik mungkin sehingga anak dapat mengikuti dengan senang tanpa di bebani dengan aturan-aturan yang bersifat kaku. Jika hal tersebut terjadi dapat menghambat tumbuh kembang anak, karena pada hakikatnya dunia anak usia dini adalah bermain. Dengan konsep tersebut, maka diproses pembelajaran di buat secara menarik mungkin dengan kondisi bermain, sehingga tercipta suasana menyenangkan yang dapat mengembangkan potensi yang di miliki secara optimal. Pernyataan tersebut sesuai dengan perinsip pembelajaran yang sejalan dengan pendapat Sofia Hartati yang menyatakan bahwa belajar dilakukan sambil bermain. Melalui bermain dapat memberi kesempatan bagi anak untuk bereksplorasi, menemukan, mengekspresikan perasaan, berkreasi, dan belajar secara menyenangkan (Hartati, 2005).

Di samping itu, guru juga memberi kesempatan kepada anak yang seluas-luasnya untuk mengungkapkan segala apa yang ada di dalam pemikiran anak dan selanjutnya untuk dikembangkan seluas-luasnya tanpa adanya aturan-aturan yang kaku. Pada pembuatan rencana kegiatan harian di Jogja Green School juga dilaksanakan bersamasama dengan guru yang lainnya pada akhir pekan, sehingga antara guru yang satu dengan yang lainnya dapat bertukan pemikiran untuk kegiatan yang akan datang. Dengan hal demikian juga dapat mengembangkan dan menyalurkan kreativitas guru yang akan bendampak positif terhadap pembelajaran dan perkembangan anak didik.

\section{Penilaian Aspek Perkembangan Bahasa di TK Jogja Green School}

Dari hasil penelitian yang dilakukan di TK Jogja Green School didapat beberapa dokumen yang berupa buku penghubung, rapor semester selain hanyalah dalam bentuk wawancara kepada beberapa siswa dan guru dengan patokan indikator pencapaian yang sudah dibuat dalam bentuk RKH.

$>$ Indikator Pencapaian pada Aspek Perkembangan Bahasa

1) Menghubungkan tulisan sederhana dengan simbol yang melambangkannya

2) Melakukan 2-3 perintah sederhana

3) Dapat menyebutkan identitas diri

4) Menulis huruf-huruf yang dikenalkan

5) Bercerita dengan panggung bangku

6) Menceritakan kembali sebuah cerita dengan jalinan yang benar

7) Mendengarkan syair dan mampu mengulang kembali

8) Menceritakan isi gambar seri

9) Memegang pensil dengan benar

Berdasarkan indikator pencapaian yang ditulis diatas kemudian dimasukan dalam laporan harian yang berbentuk narasi kegiatan sehari selama proses pembelajaran, dengan tahap akhir dimasukkan dalam laporan semester dengan nilai berupa keterangan $\mathrm{E}=$ Excellent, VG=Verry Good, $\mathrm{G}=\mathrm{Good}$. Alasan penggunaan keterangan ketiga huruf 
tersebut tidak lain dari pendapat kepala sekolah sekaligus perintis TK Jogja Green School yang bernama Ibu Eni Krisnawati beranggapan tidak ada kata tidak bisa bagi anak melainkan belum, sehingga dengan kata belum masih banyak kemungkinan untuk kedepan siswa menjadi bisa sehingga dapat diambil tindakan oleh guru selanjutnya akan dapat diputuskan model atau metode apa yang akan digunakan sesuai kebutuhan masingmasing siswa.

\section{KESIMPULAN}

Terdapat beberapa indikator ppencapaian pada aspek perkembangan bahasa, yaitu: menghubungkan tulisan sederhana dengan simbol yang melambangkannya, melakukan 2-3 perintah sederhana, dapat menyebutkan identitas diri, menulis huruf-huruf yang dikenalkan, bercerita dengan panggung bangku, menceritakan kembali sebuah cerita dengan jalinan yang benar, mendengarkan syair dan mampu mengulang kembali, dan menceritakan isi gambar seri.

\section{DAFTAR PUSTAKA}

Arikunto, Suharsimi. 2012). Dasar-Dasar Evaluasi Pendidikan. Jakarta: Sinar Grafika Offset.

Azwar, Saifudi. 2010. metode penelitian. Yogyakarta: Pustaka Pelajar.

Hartati. Sofia. 2005. Perkembangan Balajar pada AUD. Jakarta: Depdiknas.

Santrock, John W. 2007. Perkembangan Anak. Jakarta: Erlangga.

Lara, Fridani. 2009. Evaluasi Perkembangan Anak Usia Dini . Jakarta:Universitas Terbuka.

Ningsih, Jati Sri. 2013. Penilaian Aspek Bahasa Anak. Karya ilmiah. Program studi Bahasa dan Sastra Asing Fakultas Bahasa dan Seni Universitas Negeri Semarang.

Rachmawat, Yeni dan Euis Kurniati. 2005. Strategi Pengembangan Kreativitas Pada Anak Usia Taman Kanak-Kanak. Jakarta: Departemen Pendidikan Nasional.

Sugiyono.2010. Metodologi Penelitian Pendidikan Pendekatan Kuantitatif, Kualitatif dan $R \& D$. Bandung: Alfabeta.

Turisqoh, Futicha.2011. Peningkatan Kemampuan Berbahasa Anak Melalui Metode Bercerita dengan Membacakan Buku Cerita Anak Kelompok B di TK Islam Miftahul Ulum Gumayun. Karya Ilmiah. UPTDDIKPORA Kecamatan Dukuhwaru. Tegal Jawa Tengah. 